\title{
Peran Kader Masyarakat dalam Program Pengelolaan Sampah Mandiri Di Desa Karangsari, Sapuran, Wonosobo
}

\author{
Aris Slamet Widodo 1 \\ 1 Program Studi Agribisnis, Universitas Muhammadiyah Yogyakarta \\ Jl. Brawijaya, Kasihan, Bantul. \\ Email: armando1215sw@gmail.com \\ DOI: $10.18196 / p p m .36 .322$
}

\begin{abstract}
Abstrak
Desa Karangsari, Kecamatan Sapuran, Kabupaten Wonosobo telah mendeklarasikan diri sebagai desa wisata. Terkait dengan hal tersebut saat ini Desa Karangsari telah membuat program kebersihan lingkungan, khususnya pengelolaan sampah secara mandiri. Program pengabdian Desa Mitra yang dilaksanakan ini diharapkan mampu membantu masyarakat dalam menghadapi permasalahan sampah, sehingga tujuan pengabdian ini adalah pemberdayaan masyarakat dalam pengelolaan sampah mandiri dengan metode pengaderan di Desa Karangsari, Sapuran, Wonosobo. Proses pemberdayaan menggunakan metode Participatory Rural Appraisal (PRA) dan solusi yang dilaksanakan adalah peningkatan pengetahuan dan keterampilan pengelolaan sampah (3R), pembentukan kader, dan penguatan kelembagaan, inisiasi rumah pilah sampah percontohan dan kampanye serta gerakan masyarakat. Kegiatan pendampingan dilaksanakan untuk mencapai perubahan perilaku masyarakat. Tahapan pelaksanaan program adalah: need assessment, penguatan dan komitmen, program dan monitoring, terakhir pelaporan. Hasil pengabdian dapat disimpulkan bahwa pemberdayaan masyarakat Desa Karangsari dalam perubahan pengetahuan keterampilan, sikap dan perilaku dengan metode pendekatan kader dan tokoh masyarakat secara umum berhasil, yang dibuktikan dengan tingginya tingkat kehadiran masyarakat dan perangkat desa dalam tahap penyuluhan, sosialisasi, dan ditandatanginya surat komitmen oleh 387 warga dan seluruh dusun melaksanakan gerakan pemilahan sampah secara serentak. Metode penguatan kaderisasi terbukti mampu menggerakan masyarakat pada proses pemberdayaan masyarakat
\end{abstract}

Kata kunci: pemberdayaan, kader, sampah.

\section{Pendahuluan}

Desa Karangsari merupakan salah satu desa yang berada di Kecamatan Sapuran, Kabupaten Wonosobo, Jawa Tengah. Desa Karangsari memiliki luas 4,19 km² (BPS Kab. Wonosobo, 2018). Desa Karangsari memiliki lima dusun diantaranya Dusun Karangsari, Silemud, Sukosreno, Karangluas, dan Garungan. Wilayah Desa Karangsari merupakan daerah perbukitan yang sebagian besar penduduknya bermata pencaharian petani, penggergaji kayu, dan yang lainnya sebagai buruh di pabrik dan di penggergajian. Penduduk di Desa Karangsari sebagian besar menganut agama Islam. Kondisi sosial warga di Desa Karangsari termasuk sudah aktif dengan adanya kegiatan rutin yang biasa dilakukan oleh orang tua maupun pemuda. (Monografi Desa Karangsari, 2019).

Desa Karangsari memiliki potensi area pertanian tanaman pangan dan sebagian besar perkebunan tanaman tahunan seperti tanaman keras yaitu sengon dan tanaman perkebunan yaitu kopi, jenis robusta. Selain itu Desa Karangsari merupakan area industri penggergajian kayu dan bahan baku kayu berasal dari luar daerah serta limbah dari penggergajian kayu tersebut sebagian besar belum dikelola atau termanfaatkan dengan baik. Dampak dengan adanya usaha industri 
penggergajian adalah adanya sampah atau limbah di area pabrik. Sampah menjadi salah satu fokus dalam program desa yang harus dikelola dengan baik. Hal tersebut terkait dengan adanya potensi sungai yang memiliki potensi wisata karena keindahannya dan karena keunikannya sehingga Desa Karangsari pada tahun 2018 sudah mencanangkan program wisata sungai. Program wisata sungai tersebut didukung potensi yang lainnya yaitu perkebunan kopi dan budaya masyarakat setempat. Sebagai desa destinasi wisata, maka menjadi perhatian penting adalah sampah.

Tahapan pengelolaan sampah di Desa Karangsari sudah dimulai tahun 2018 dan baru tahap sosialisasi dan penyuluhan pentingnya pengelolaan sampah. Belum pada tahap praktik dan pendampingan serta belum juga memasukan inovasi dan teknologi dalam pengelolaan sampah tersebut. Usaha pengelolaan dan penanganan sampah tersebut dilakukan untuk mendukung program desa wisata sungai.

Terkait dengan hal tersebut atas kesepakatan dengan pihak Desa maka tujuan pengabdian adalah "pemberdayaan masyarakat dalam pengelolaan sampah mandiri menggunakan metode pengaderan di Desa Karangsari, Sapuran, Wonosobo".

\section{Metode Pelaksanaan}

Metode pelaksanaan yang digunakan dalam program pemberdayaan pengelolaan sampah mandiri adalah Participatory Rural Appraisal (PRA) dengan memanfaatkan potensi yang ada dan partisipasi masyarakat terutama kader dan tokoh masyarakat. Pendekatan PRA memungkinkan keterlibatan secara utuh dari berbagai unsur dan lapisan sosial yang ada di masyarakat (Widodo, A.S, 2019). Tahapan pelaksanaan program adalah sebagai berikut:

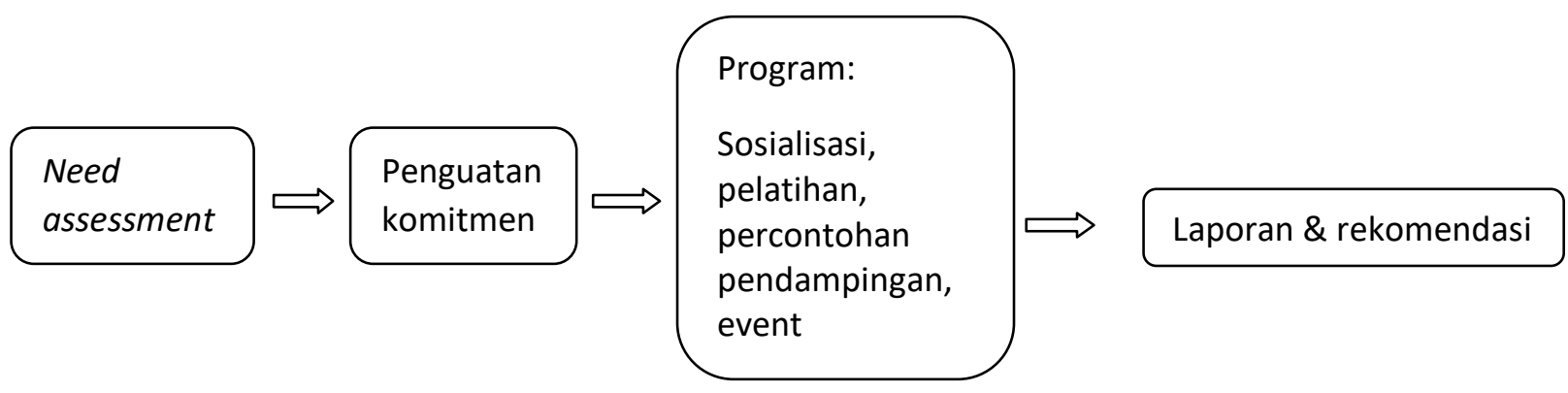

Bagan 1. Tahapan Pelaksanaan Program

\section{Hasil dan Pembahasan}

Secara teori bahwa karakter program pemberdayaan masyarakat ada 3 (tiga) hal yaitu (1) berbasis kelembagaan (community base), berbasis sumberdaya lokal (local resource base) dan berkelanjutan (sustainable). Program pemberdayaan pengelolaan sampah rumah tangga di Desa 
Karangsari, Wonosobo ini mencoba menerapkan ketiga karakter program dalam implementasinya. Community-base, pemberdayaan akan efektif dan efisien apabila dilaksanakan melalui lembaga yang ada di masyarakat.

\section{Tahapan Pemberdayaan Masyarakat di Desa Karangsari, Wonosobo.}

\section{Tahap Informasi awal atau observasi}

Informasi awal merupakan langkah pertama dan merupakan tahapan penting dalam pemberdayaan masyarakat. Dalam teori analisa sosial bahwa tahap identifikasi setiap stakeholder yang terlibat serta mengetahui profil dari setiap stakeholder merupakan informasi penting dalam analisa sosial. Hasil analisa sosial dalam diagram Venn dari profil setiap stakeholder yang terdiri dari Power, Interest dan Legitimacy akan menjadi landasan pembuatan strategi bagi seorang fasilitator di dalam melibatkan stakeholder yang berada dalam lingkaran pemberdayaan masayarakat. Permasalahan sampah di Desa Karangsari, jelas bahwa stakeholder yang terlibat adalah Rumah tangga, Perangkat Desa, Kader Masyarakat, lembaga APPEL dan Dinas Lingkungan Hidup Kabupaten Wonosobo. Lima stakeholder tersebut akan memiliki peran masing-masing dalam mengatasi permasalahan sampah.

\section{Tahap Pembauran}

Makna pembauran adalah melakukan kegiatan seperti yang dilakukan masyaraka dalam keseharian, seperti ke sawah/ladang, kegiatan sosial, ke masjid, makan, dll. Inti dari pembauran adalah ikut berbaur dalam kegiatan masyarakat. Kegiatan yang diikuti baik itu aktivitas yang sifatnya incidental maupun aktivitas harian. Pembauran ini kerap dikenal dengan istilah "Immersion" yang artinya berbaur. Tahap ini sangat penting karena bisa menjadi kunci keberhasilan diterimanya fasilitator di tengah masyarakat yang kemudian memberikan dampak pada kesediaan masyarakat untuk bergerak melakukan perubahan.

\section{Tahap need assessment}

Kegiatan need assessment yang dilakukan di Desa Karangsari dilaksanakan melalui 2 tahap yaitu dengan wawancara dan Focus Group Discussion (FGD). Wawancara dilaksanakan kepada stakeholder yang terlibat dalam tahap analisa sosial dengan cara mendatangi masyarakat ke rumah, yaitu: perangkat desa, kader masyarakat, kepala rumah tangga, dinas lingkungan hidup dan pengurus APPEL, serta tokoh masyarakat (Ustadz, Guru, Ketua Karang Taruna, Ketua RT dan RW). 
Tahapan Focus Group Discussion (FGD), dilaksanakan di Balai Desa Karangsari. Kegiatan tersebut mengundang semua stakeholder yang akan terlibat dalam pelaksanaan pemberdayaan dan mereka yang telah diwawancarai. FGD dilaksanakan selama 1 (satu) kali dipandu oleh fasilitator dengan dibantu seorang notulensi. Kegiatan dilaksanakan di Balai Desa Karangsari, pada hari Minggu, tanggal 29 Desember 2019, jam 13.00 - 15.00. Kegiatan FGD tersebut difasilitasi oleh pihak perangkat desa Karangsari. Masyarakat dan stakeholder yang diundang dalam FGD berjumlah 32 orang (Kepala Desa, Kepala Dusun, Ketua Takmir Masjid/Musholla, Ketua PKK tingkat Desa, Kader PKK tiap Dusun, Ketua dan anggota Karang Taruna, Perwakilan APPEL Wonosobo, Tim Fasilitator). Hasil diskusi dari beberapa tokoh masyarakat dapat disimpulkan bahwa permasalahan sampah penting sehingga diperlukan program pemberdayaan pengelolaan sampah.

\section{Pelaksanaan}

Hasil dari need assessment akan menjadi landasan penentuan program pemberdayaan yang akan dilaksanakan. Keresahan masyarakat terhadap permasalahan sampah di Desa Karangsari dan adanya harapan masyarakat untuk menginisiasi wisata sungai, maka masyarakat memandang perlunya penanganan sampah rumah tangga. Terkait dengan kondisi tersebut maka diperlukan strategi pelaksanaan program pengelolaan sampah rumah tangga. Strategi tersebut disusun bersama dengan masyarakat melalui focus grup discussion. Tahapan pelaksanaan pemberdayaan adalah sebagai berikut:

a) Sosialisasi masyarakat di Desa Karangsari tentang "Kesadaran masyarakat terhadap kebersihan lingkungan".

b) Pembentukan kader pilah sampah

c) Gerakan pilah sampah

Kedua program tersebut dilaksanakan berurutan, dengan dukungan perangkat desa, kelompok APPel Wonosobo dan masyarakat.

\section{a). Kegiatan Sosialisasi.}

Program sosialisasi sampah yang ditujukan kepada ibu-ibu PKK dan kader berlangsung pada tanggal 12 Januari 2020 bertempat di Balai Desa Karangsari pada pukul 14.00 WIB 17.00 WIB. Acara ini dihadiri langsung oleh Bapak gunawan selaku perwakilan dari Aksi Pendekar Peduli Lingkungan (APPEL), Edy Sucipto S.P selaku Kepala Desa Karangsari, dan Bapak serta Ibu Camat Sapuran.

Materi sosialisasi terkait akan diadakan sebuah program desa yang diharapkan mampu memberikan solusi terkait sampah yang menjadi masalah setiap orang. Diawali dengan 
dibentuknya suatu program panitia sedekah sampah, yang dapat memfasilitasi Ibu-ibu kader untuk membuang sampahnya hingga bernilai jual dan bermanfaat. Sosialisasi tahap awal ini diutamakan bagi ibu-ibu rumah tangga karena ibu-ibu dianggap lebih tahu terhadap sampah yang dihasilkan rumah tangga serta faktor utama penghasil sampah adalah rumah tangga.

\section{b). Inisiasi Pembentukan Panitia Pengelola Sedekah Sampah}

Inisiasi pembentukan Pengelola Sedekah Sampah, dilaksanakan pada tanggal 19 Januari 2020 yang bertempat di Balai Desa Karangsari pada pukul 14.00 WIB - 17.00 WIB. Peserta yang diundang dalam pertemuan ini adalah tokoh masyarakat seperti RT, RW, Takmir Masjid, dan Kader Penggerak Masyarakat. Acara kegiatan ini dimulai dengan pembukaan, pembacaan ayat suci al-Qur'an, menyanyikan lagu kebangsaan Indonesia, kemudian sambutan oleh Kepala Desa Karangsari Bapak Edy Sucipto S.P dan dilanjutkan oleh pemateri yaitu Dr. Aris Selamet Widodo.

Pemateri menjelaskan tentang program sedekah sampah yang merupakan kegiatan mengelola sampah dengan memilah sampah yang bernilai jual untuk diserahkan kepada panitia atau amil yang sudah ditunjuk atau ditetapkan guna tujuan sosial. Pemateri mengajak para takmir masjid dan kader untuk bersama-sama peduli akan lingkungan sekitarnya. Kepedulian tersebut diwujudkan dengan bersedia andil dalam penanganan masalah sampah di lingkunganya dan bersedia menjadi panitia sedekah sampah. Tugas panitia sedekah sampah adalah mengkoordinasi kegiatan pengumpulan dan penyaluran program sedekah sampah yang akan dilaksanakan di tiap-tiap dusun dengan akad yang jelas dan pembukuan yang tertib dan transparan.

Akhir dari pertemuan tersebut akhirnya dari tiap tiap dusun ada beberapa orang tokoh dan kader masyarakat yang bersedia untuk menginisiasi pembentukan panitia sedekah sampah. Tokoh dan kader tiap dusun diberikan kesempatan untuk menyusun kepengurusan pengelola sedekah sampah. Dusun yang siap menyusun kepengurusan adalah Dusun Karangsari, Sukosreno, Silemud, Karangluas, dan Garungan.

\section{c). Pelantikan Pengelola Sedekah Sampah}

Tahap ketiga adalah pelantikan pengelola sedekah sampah tiap dusun. Kegiatan pelantikan panitia sedekah sampah dilanjutkan dengan penyuluhan konsep sedekah sampah dan teknis pelaksanaan. Kegiatan tersebut dilaksanakan pada tanggal 27 Januari 2020 yang bertempat di Balai Desa Karangsari pada pukul 14.00-17.00 WIB. Kegiatan dihadiri oleh perwakilan dari Dinas Lingkungan Hidup Kabupaten Wonosobo yaitu Drs. Oman Yanto, MM. , 
Kepala Desa Karangsari Edy Sucipto, SP., perwakilan organisasi Aksi Pendekar Peduli Lingkungan (APPEL) yaitu Bp. Gunawan serta Fasilitator dari LP3M UMY Dr. Aris Slamet Widodo.

Pelantikan pengelola sedekah sampah tiap dusun yaitu sebanyak 5 dusun dan pembacaan sumpah dipimpin oleh Kepala Desa Karangsari serta diikuti oleh seluruh pengelola yang dilantik secara bersama sama. Selanjutnya dilaksanakan penandatanganan surat pengangkatan sebagai pengelola sedekah sampah antara Kepala Desa Karangsari untuk periode 2020 - 2024.

Setelah pelantikan, acara dilanjutkan dengan arahan tentang tahapan pelaksanaan program sedekah sampah oleh Dr. Aris Slamet Widodo, SP., MSc. Tahapan pelaksanaan secara umum adalah sebagai berikut: (1) penyusun Alur Kerja / Standar Prosedur Operasional (SOP); (2) pembagian peran dalam pelaksanaan Sedekah sampah; (3) simulasi; (4) gerakan sedekah sampah secara bersama sama oleh seluruh dusun, dan (5) evaluasi.

Acara ditutup dengan informasi peluang kerjasama dengan Aksi Pendekar Peduli Lingkungan Hidup (APPEL) Kabupaten Wonosobo. Perwakilan APPEL, Bp Gunawan menjelaskan bahwa APPEL bersedia membeli hasil pengumpulan sampah yang memiliki nilai jual, seperti plastik, kardus dan besi/ logam.
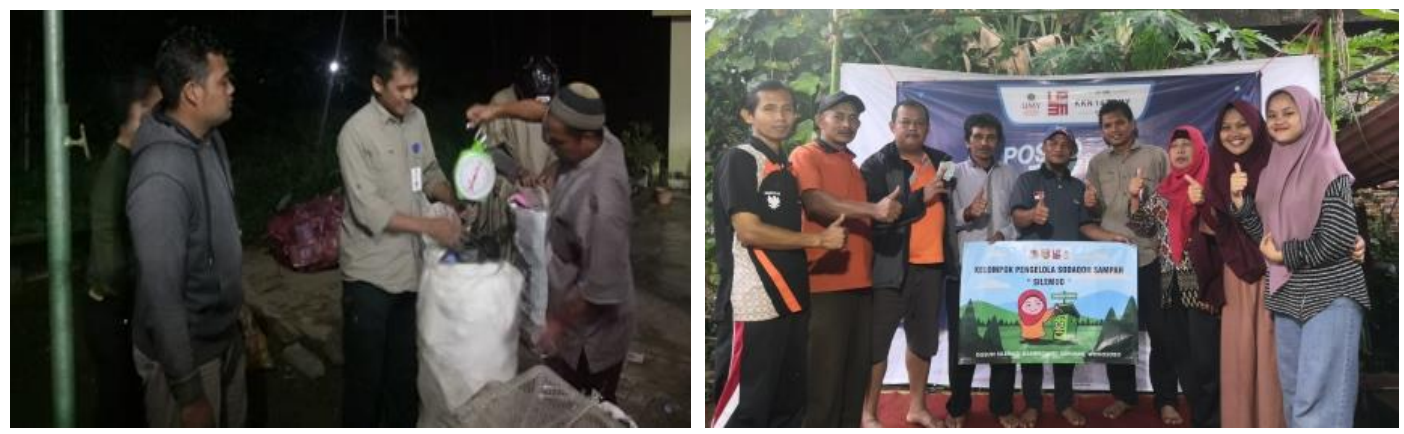

\section{d). Penandatanganan Surat Komitmen dan Pemberian Sertifikat Penghargaan}

Teknik pemberdayaan masyarakat yang diterapkan dalam program sedekah sampah di Desa Karangsari, Kabupaten Wonosobo adalah pendekatan teknik pendidikan orang dewasa (POD). Pendekatan ini menitikberatkan pada perilaku orang dewasa dimana orang dewasa memiliki pengalaman dan pengetahuan yang cukup membantunya berfikir dan mengambil keputusan yang logis berdasarkan nilai-nilai yang dipercayainya. Kepemilikan atas nilai nilai tersebut menyebabkan orang dewasa merasa perlu dihargai oleh orang lain dan harga diri tersebut menjadi perwujudan besar - kecil atau tinggi-rendah dirinya dibandingkan orang lain. 


\section{2}

Komitmen menjadi salah satu alasan mengapa orang dewasa memiliki harga diri, sehingga pendekatan pemberdayaan dengan teknik penandatanganan surat komitmen dan sertifikat penghargaan menjadi tepat untuk diterapkan. Surat komitmen ada dua jenis yaitu:

1) Surat komitmen yang ditandatangani oleh warga (perwakilan kepala rumah tangga) bahwa keluarga tersebut berkomitmen menyelamatkan lingkungan hidup dengan memilah dan mensedekahkannya kepada pihak pengelola sedekah sampah di dusunnya dan diketahui oleh kepala desa.

2) Surat komitmen yang ditandatangani oleh pengelola sedekah sampah bahwa dirinya berkomitmen untuk menyelamatkan lingkungan hidup dengan bersedia sebagai pengelola sedekah sampah di dusunnya dan diketahui kepala desa.

Selain surat komitmen, di dalam program ini juga disiapkan sertifikat penghargaan dan ada dua jenis penghargaan yaitu:

1) Sertifikat penghargaan yang diberikan kepada setiap keluarga yang telah bersedia berkontribusi didalam penyelamatan lingkungan hidup dengan melakukan pemilahan dan menyedekahkannya kepada pengelola sedekah sampah di dusunnya. Sertifikat diberikan oleh Kepala Desa Karangsari dan diketahui oleh Kepala Dinas Lingkungan Hidup Kab. Wonosobo.

2) Sertifikat penghargaan yang diberikan kepada setiap pengelola sedekah sampah yang telah bersedia mewakafkan waktu dan tenaganya untuk penyelamatan lingkungan hidup dengan berperan sebagai pengelola sedekah sampah di dusunnya. Sertifikat diberikan oleh Kepala Desa Karangsari dan diketahui oleh Kepala Dinas Lingkungan Hidup Kab. Wonosobo.

Penandatanganan surat komitmen dan pemberian sertifikat bagi pengelola sedekah sampah secara simbolis dilaksanakan di Balai Desa pada tanggal 1 Februari 2020, jam 09.00-10.00 WIB. Pada pelantikan pengelola sedekah sampah ini setiap pengelola yang sudah dilantik langsung menandatangani surat komitmen dan dilanjutkan penyerahan setifikat, kaos panitia, buku besar dan buku arus kas, kuitansi, serta timbangan manual untuk tiap dusun.

Pemberian surat komitmen warga juga dilaksanakan pada tanggal 1 Februari 2020, jam 10.00 - 17.00 di Balai Desa. Warga yang telah menandatangani surat komitmen akan mendapatkan 1 (satu) buah tas karung sebagai alat untuk memilah dan membawa sampah yang akan disedekahkannya serta mendapatkan sertifikat penghargaan. Berdasarkan presensi yang hadir untuk penandatangan surat komitmen warga adalah sejumlah 387 kepala keluarga.

\section{e). Simulasi}


Tahap simulasi dilaksanakan menjelang gerakan sedekah sampah yang akan dilaksanakan secara serentak dalam satu desa. Simulasi dihadiri oleh panitia sedekah sampah setiap dusun di Desa Karangsari yang bertujuan untuk memberikan arahan terkait teknis program sedekah sampah. Simulasi dilaksanakan pada tanggal 6 Februari 2020, jam 15.00 WIB dan dihadiri oleh seluruh pengelola sedekah sampah dari 5 dusun. Dalam simulasi tersebut dipimpin oleh fasilitator yaitu Dr. Aris Slamet Widodo, SP., M.Sc.

Kegiatan diawali dengan pemahaman sedekah dan keharusan niat dalam bersedekah, dilanjutkan dengan training pentingnya teamwork yang baik, dan alur kerja. Pada saat warga datang, ada pengelola sedekah sampah yang senantiasa mengingatkan tentang pentingnya niat dalam bersedekah. Kemudian untuk training kerjasama tim dilakukan dengan permainan tembak-tembakan yang inti dari permainan adalah pentingnya pembagian peran bagi seluruh anggota agar sistem berjalan dengan baik dan setiap pengelola yang terlibat merasa dihargai.

Penjelasan alur kerja atau SOP dalam pelaksanaan sedekah sampah diawali dengan setting tempat, ada 3 (tiga) area utama yaitu:

1. Area penimbangan barang

2. Area akad, pembukuan dan pemberian kuitansi

3. Area penerimaan barang, pemilahan dan pergudangan/penyimpanan.

Setelah dibagi area, kemudian pembagian kerja pengelola yang dibagi tiap area. Simulasi tidak hanya sampai pada penerimaan sampah tetapi juga sampai pemberian uang hasil sedekah kepada masyarakat terpilih yang memenuhi persyaratan sebagai penerima.

\section{f). Gerakan Sedekah Sampah}

Gerakan sedekah sampah dilaksanakan secara serentak, diseluruh dusun di Desa Karangsari pada tanggal 7 Februari 2020 pada pukul 13:00. Dusun Karangsari yang dijadikan sebagai titik pengumpulan sampah yaitu di halaman Masjid Baiturahman, Dusun Sukosreno titik pengumpulan sampah berada di halaman Posko KKN 034, Dusun Silemud titik pengumpulan sampah berada di posko KKN 142, Dusun Karangluas titik pengumpulan sampah berada di halaman rumah salah satu panitia program sedekah sampah, dan Dusun Garungan titik pengumpulan sampah berada di halaman rumah Ketua RT.

Setiap warga diarahkan untuk membawa karung berisi sampah yang sudah terpilah ke titik pengumpulan sampah tiap dusun kemudian sampah yang sudah disetorkan oleh warga kepada panitia selanjutnya akan langsung diproses oleh panitia sedekah sampah mulai dari pemilahan, penimbangan, dan pencatatan berat sampah serta nama masyarakat yang membawa sampah. Setelah sampah terpilah dan terkumpul selanjutnya pihak APPEL mengambil sampah 
di titik tiap Dusun dan langsung dilakukan proses pembayaran sampah tersebut, selanjutnya uang hasil penjualan sampah saat itu juga langsung diserahkan kepada masyarakat yang membutuhkan atau kegiatan sosial dusun. Hasil gerakan sedekah sampah pada hari pertama terlampir.

\section{Simpulan}

1. Pemberdayaan masyarakat Desa Karangsari dalam program pengelolaan sampah mandiri telah berhasil meningkatkan partisipasi masyarakat yang dibuktikan dengan tingginya tingkat kehadiran masyarakat dan perangkat desa dalam tahap penyuluhan, sosialisasi dan ditandatanginya surat komitmen oleh 387 warga dan seluruh dusun melaksanakan gerakan pemilahan sampah seara serentak.

2. Metode penguatan kaderisasi dan tokoh masyarakat terbukti mampu menggerakan masyarakat pada proses pemberdayaan masyarakat.

\section{Ucapan Terima Kasih}

Terima kasih kami sampaikan kepada seluruh perangkat dan warga Desa Karangsari, Sapuran, Wonosobo yang telah aktif berkontribusi dalam pelaksanaan program dan Lembaga Penelitian, Publikasi dan Pengabdian Masyarakat (LP3M UMY yang telah memberikan support materi dan pembiayaan.

\section{Daftar Pustaka}

BPS Kab. Wonosobo, 2018. Kabupaten Wonosobo dalam Angka 2018. https://wonosobokab.bps.go.id/.

Caslay, Dennis J dan Khrisna Kumar (1991). Pemanfaatan dan Evaluasi Proyek Pertanian. Terjemahan, Jakarta UI.

Kusumaningrum W.I, Wahyu Hardyanto, Murwatiningsih, 2014. Model Manajemen Pelatihan Berbasis Partisipatif. Jurnal Penelitian Tindakan Sekolah dan Kepengawasan. Vol. 1, No. 2. Oktober 2014. ISSN 2355-9683

Lindriati, S., Suntoro, I., Pitoewas, B. 2017. Pengaruh Sosialisasi Dan Tingkat Pemahaman Masyarakat Terhadap Minat Pembuatan Akta Kematian Di Desa Purworejo. Artikel penelitian. Fakultas Keguruan dan Ilmu Pendidikan. Universitas Lampung.

Luthans, Fred, 2005, Perilaku Organisasi, Edisi 10, Andi Offset, Yogyakarta.

Mowday, R.T., Steers, R.M., dan Porter, L.W., 1982, Employee Organization Linkage: The Psychology of Commitment, Absenteism, and Turnover, Academic Press, New York.

Monografi Desa Karangsari, 2019. https://karangsari-sapuran.wonosobokab.go.id/ 
Siswanti, A.D., Muadi, S., Chawa A.F., 2016. Peran Pendampingan Dalam Program Pemberdayaan Masyarakat (Studi Pada Program Pendampingan Keluarga Balita Gizi Buruk di Kecamatan Semampir Kota Surabaya. Jurnal Wacana-Vol. 19, No. 3 (2016) ISSN : 1411-0199 E-ISSN: 2338-1884

Widodo, A.S., 2019. Teknik Pemberdayaan Masyarakat. Lembaga Penelitian, Publikasi dan Pengabdian Masyarakat (LP3M). Universitas Muhammadiyah Yogyakarta.

Yamin, Martinis. 2013. Strategi dan metode dalam model inovasi pembelajaran. Jakarta: Gaung Persada Press Group. 